\title{
EFFECTS OF THE NONSTEROIDAL ECDYSONE AGONIST, TEBUFENOZIDE, ON LIVER CYP ACTIVITIES
}

\author{
BY \\ Abdou, Rania H \\ Forensic Medicine and Toxicology Department, Suez Canal University, Ismailia 41522, Egypt
}

\begin{abstract}
The non-steroidal ecdysone agonist tebufenozide was orally administered to Wistar rats for 5 days to examine their effects on the liver cytochrome P450 (CYP) activities. Also Michaelis-Menten kinetics of the metabolic reactions catalyzed by liver CYPs were studied after adding tebufenozide to the assay system to investigate its possible inhibitory effects on liver CYPs activities. These reactions included ethoxyresorufin O-deethylation, tolbutamide hydroxylation, bufuralol $1 \square$-hydroxylation, and midazolam 1,4-hydroxylation, for CYP1A, 2C, 2D, and 3A activities, respectively. Results revealed no any significant alteration in the activities of the tested microsomal enzymes after oral administration of tebufenozide. none of the examined CYPs was inhibited by tebufenozide as the Ki values were very high (more than $9000 \mu \mathrm{M})$. We can conclude that tebufenozide is considered safe and can be a good alternate for the traditional insecticides.
\end{abstract}

KEY WORDS: CYP, enzyme induction, enzyme inhibition, tebufenozide, rat

\section{INRTODUCTION}

P450 iso enzymes (CYPs) are a large family of heme-containing monooxygenase found on the membranes of smooth endoplasmic reticulum. These enzymes are responsible for biotransformation of most foreign substances and, therefore, have essential roles in detoxification of many chemicals. (Abdou et al., 2010 ; Schneider and Clark 2013). Cytochrome P450 enzymes also contributed in the biosynthesis of a variety of molecules inside the body as steroids and cholesterol (Lynch and Price 2007). Basic understanding of human CYP450s is well- established while, the animal P450s are still essential in the issues of metabolism and safety testing (Guengerich , 2008). Many chemicals have the ability to induce 
or inhibit Cytochrome P450 enzymes (Bibi, 2008). As it is impossible to avoid chemical exposure, the alterations in CYP activities not only adversely affect our health, but also it have harmful effects on environmental lives. Effects of drugs on CYP activities are well recognized while; those of other categories of xenobiotics are not yet, even if their toxicological profiles have been established (Glue and Clement, 1999 ; Abdou et al., 2010).

Insecticides are one of the chemicals that we are commonly exposed. The third-generation insecticides, insect growth regulators (IGRs), is a new class of bio-rational compounds that widely used to control insect pests through their adverse affects on the growth and/or development of the insects, they are classified according to the mode of action into ecdysone (steroid molting hormone) agonists such as tebufenozide, juvenile hormone mimics as pyriproxyfen and chitin synthesis inhibitors as diflubenzuron (Tasei, 2001, Tunaz and Uygun, 2004, Merzendorfer et al., 2012 and Sadanandane et al., 2012). The IGRs are fitting the modern insect pest management principles owing to their great selectivity in their mode of action and quite efficacy (Staal, 1975, Hami et al., 2005 and Suman et al 2013).

The non-steroidal ecdysone agonist tebufenozide (RH-5992), 4-ethylbenzoic acid- N'tert-butyl- N'-(3,5-di-methylbenzoyl) hydrazide, is a fat-soluble insecticide that is potent and selective in control of Lepidoptera pests in a variety of crops Under the trade names Confirm ${ }^{\circledR}$, Mimic ${ }^{\circledR}$, and Romdan ${ }^{\circledR}$,. It mimics the action of the insect molting hormone; resulting in a lethal unsuccessful molt (Carlson, 2000, Retnakaran et al., 2001 and Hamadah et al., 2012). Tebufenozide has been classified by US environmental agency (EPA) as reduced risk pesticide because of its low acute and chronic toxicity in avian and mammals. When given orally, dermally, or by inhalation, no deaths or clinical signs of systemic toxicity were observed at doses $<5.0 \mathrm{~g} / \mathrm{kg}$ bw. Mammalian studies revealed no evidence of carcinogenicity for tebufenozide (Gilbert, 2009).

From the mentioned facts, insect growth regulators may consider to be safe for human and animals as well as the environment. To our knowledge, however, their effects on CYP enzymes not sufficiently cleared and further researches are still needed to proof their safety. They may affect the metabolism of many other compounds and xenobiotics to which we are exposed daily other than the biotransformation of endogenous substances. If so, the idea about this group of pesticide may be changed and cautions must be taken when use it as in case of the other generations of the commercial pesticides. Subsequently, our target in this Study was to clarify the possible effects of tebufenozide, as an example of this group of Pesticides, on liver CYP enzyme activities in rats. 


\section{MATERIALS AND METHODS}

Animals: A total of 15 male Wistar rats were allowed to accustomed to the environment for at least 1 week before the beginning of the experiment. At the start of the experiment, their ages and body weights were 9 weeks and 210-230 g, respectively. The animals were kept in ventilated room under controlled laboratory conditions of temperature $25-28^{\circ} \mathrm{C}$ and humidity of $55-70 \%$ with $12-\mathrm{hr}$ light/dark cycle, they provided with free access to water and fed on commercial pellets.

Chemicals: tebufenozide, Resorufin and ethoxyresorufin, Tolbutamide, hydroxytolbutamide, midazolam, 1-hydroxymidazolam, 4-hydroxymidazolam, bufuralol and $1 \square$-hydroxybufuralol were purchased from Sigma Chemical Co. (St. Louis, MO, U.S.A.). All used chemicals were of analytical or HPLC grade.

\section{Experimental design,}

In vivo study: Effects of tebufenozide on activities of CYP1A, 2C, $2 \mathrm{D}$ and $3 \mathrm{~A}$ subfamilies were studied in rats. rats were divided into three groups (five of each); first group managed as control and administered corn oil (as a vehicle) for 5 days using a stomach tube, the other two groups were given tebufenozide orally for 5 days at 30 and $100 \mathrm{mg} / \mathrm{kg}$ as the LD50s is more than 1,000 mg/kg (FAO/WHO, 1996 and Abdou et al., 2010). After $24 \mathrm{hr}$ of the last dose, rats were sacrified under a deep anesthesia with diethyl ether, and the liver was isolated and immediately perfused with ice-cold buffer $(1.15 \% \mathrm{KCl}, 0.2 \mathrm{mM}$ EDTA-2Na, 0.1 $\mathrm{mM}$ dithiothreitol, $0.1 \mathrm{mM}$ phenyl methyl sulphonyl fluoride, and $20 \%$ glycerol) until the efflux perfusion buffer was free of blood. Liver was cut into small parts and stored at $-80^{\circ} \mathrm{C}$ till preparation of microsomes.

In vitro study: In this study inhibitory effects of tebufenozide on CYP1A, 2C, 2D, and $3 \mathrm{~A}$ activities were also investigated using the liver microsomes obtained from the control group of the previous experiment. tebufenozide was dissolved in dimethyl sulfoxide (DMSO) then added to the enzyme assays in a volume of $10 \mathrm{ul}$. The final concentration of tebufenozide in assay system was $1,000 \mathrm{uM}$.

Preparation of hepatic microsomes: microsomes were prepared from the hepatic peices using the differential centrifugation method (Van der Hoeven and Coon, 1974), then stored at $-80^{\circ} \mathrm{C}$ until being used. Protein content of the microsomal samples was determined by protein assay kits and bovine serum albumin using the spectrophotometer (Bradford, 1976). 
Enzyme-assays: The activities of CYP1A, 2C, 2D, and 3A were determined by ethoxyresorufin O-deethylation (EROD), tolbutamide hydroxylation (TBH), bufuralol $1 \square$ -

hydroxylation $(\mathrm{BLH})$, midazolam 1-hydroxylation and midazolam 4-hydroxylation $(\mathrm{MDZH})$, respectively. The reaction was carried out at $37^{\circ} \mathrm{C}$ in a reaction mixture containing NADPH generating system [50 mM phosphate buffer (pH 7.4), $0.5 \mathrm{mM} \beta-\mathrm{NADP}^{+}, 5 \mathrm{mM}$ glucose-6-phosphate, 1.5 unite/ml glucose 6-phosphate dehydrogenase and $5 \mathrm{mM} \mathrm{MgCl} 2$, liver microsomes, and a substrate at different concentrations (total volumes were $0.25 \mathrm{ml}$, except for EROD they were $1 \mathrm{ml}$ ). Before adding the substrate, the mixtures were incubated at $37^{\circ} \mathrm{C}$ for 5 -min.

Determination of CYP1A activity: The metabolite of ethoxyresorufin, resorufin, was determined using the fluorometric method described by Burke et al., 1977. The concentration of ethoxyresorufin in the assay system was $2 \mathrm{uM}, 10$-folds higher than the $\mathrm{Km}$ value $(0.227$ $\mathrm{uM}$ ) that reported in rats (Hanioka et al., 2000). In the inhibition study, concentrations of ethoxyresorufin in the assay system were from 0.82 to $4.1 \mathrm{uM}$. Reactions were stopped by adding $3 \mathrm{ml}$ of methanol $15 \mathrm{~min}$ after the substrate, followed by centrifugation at 2,000 $\mathrm{g}$ for $5 \mathrm{~min}$, then transport $1 \mathrm{ml}$ of the supernatant into a clean test tube, diluted with $4 \mathrm{ml}$ of methanol, and applied to a spectrophotometer (RF-1500; Shimadzu Corporation, Kyoto, Japan). Excitation and emission wavelengths were adjusted at 550 and $586 \mathrm{~nm}$, respectively.

Determination of CYP2C activity: The metabolite of tolbutamide, hydroxytolbutamide, was calculated using HPLC with UV detection (Miners et al., 1988). The concentration of tolbutamide in the assay system was $10 \mathrm{mM}, 5$-folds higher than the $K m$ value $(1.91 \mathrm{mM})$ recorded in rats (Easterbrook et al., 2001). In the inhibition study, add tolbutamide to the assay system in concentrations ranged from 1 to $10 \mathrm{mM}$ then, incubate for $30 \mathrm{~min}$. The reactions were stopped by addition of $0.15 \mathrm{M}$ phosphoric acid $(0.25 \mathrm{ml})$. Chlorpropamide solution $(10 \mathrm{ug} / \mathrm{ml})$ was used as an internal standard. $3 \mathrm{ml}$ of diethyl ether were added to the samples. After centrifugation at $2,000 \mathrm{~g}$ for $5 \mathrm{~min}$, the superficial organic layer was transmitted to a clean pear-shaped flask and evaporated until dryness under low pressure. Reconstitute the residue with $500 \mathrm{ul}$ of mobile phase, then inject $50 \mathrm{u} l$ of the solution into a reversed-phase column (TSK-gel ODS- 120, 4.6×250 mm; TOSOH Co., Tokyo, Japan), UV absorbance was set at $230 \mathrm{~nm}$. The mobile phase composed of $50 \mathrm{mM}$ phosphate buffer $(\mathrm{pH}$ 4.3) and acetonitrile $(75: 25, \mathrm{v} / \mathrm{v})$ and the flow rate was $1 \mathrm{ml} / \mathrm{min}$. 
6 - 9 September 2014

Determination of CYP2D activity: The metabolite of bufuralo1, 1 $\square$-hydroxybufuralol, was evaluated using HPLC by the fluorometric method (Kronbach et al., 1987). The concentration of bufuralol in the assay system was $50 \mathrm{uM}$, which is almost 10 -folds higher than the Km value $(6.4 \mathrm{uM})$ recorded in rats (Chow et al., 1999). In the inhibition study, bufuralol was added at concenterations ranged from 4 to $134 \mathrm{uM}$. After the addition of bufuralol, the tubes were incubated for $10 \mathrm{~min}$, and the reaction was stopped by $30 \mathrm{ul}$ of $60 \%$ perchloric acid. Centrifuge at $10,000 \mathrm{~g}$ for $2 \mathrm{~min}$ to precipitate the denatured protein, then inject $50 \mathrm{ul}$ of the supernatant into the ODS column. The mobile phase contained $1 \mathrm{mM}$ perchloric acid and acetonitrile $(65: 35, \mathrm{v} / \mathrm{v})$ and the flow rate was $1 \mathrm{ml} / \mathrm{min}$. Excitation and emission wavelengths were adjusted at 252 and $302 \mathrm{~nm}$, respectively.

Determination of CYP3A activity: The metabolite of midazolam, 1,4hydroxymidazolam, was analyzed using HPLC with UV-detection method Kuroha et al. (2002). The concentration of midazolam in the assay system was $214 \mathrm{uM}$, which is about 10folds higher than the $\mathrm{Km}(22 \mathrm{uM})$ estimated in rats (Kotegawa et al., 2002). In the inhibition study, midazolam was added to the assay system at concentrations from 15 to $214 \mathrm{uM}$ then the mixture was incubated for $10 \mathrm{~min} .0 .25 \mathrm{ml}$ of acetonitrile was used to stop the reaction then placed on ice for $3 \mathrm{~min}$ and centrifugation at 10,000 $\mathrm{g}$ for $2 \mathrm{~min}$, the consequential supernatant was applied to the ODS column. The mobile phase composed of $100 \mathrm{mM}$ of acetate buffer ( $\mathrm{pH} 4.7)$, acetonitrile and methanol (59.4:35:5.6, v/v/v). Column overflow was detected by UV absorbance at $254 \mathrm{~nm}$. The flow rate was $1 \mathrm{ml} / \mathrm{min}$.

\section{Michaelis-Menten kinetic analysis:}

The following equation was applied to indicate the relation between reaction velocities (V) and substrate concentrations (S) to analyze the enzyme kinetics;

$$
V=\operatorname{Vmax} /(1+(K m / S))
$$

In this equation, Vmax and $\mathrm{Km}$ represent maximal reaction velocity and MichaelisMenten constant, respectively. By application of double reciprocal plot we find that the inhibition manner was noncompetitive so, the following equation was used to express the kinetic profile of enzyme inhibition;

$$
V=\underline{\max /(1+I / k i) \times S}
$$

$k m+S$ 
Where $\mathrm{Ki}$ is the inhibition constant, and $\mathrm{I}$ is the inhibitor concentration. The fitting program MULTI created by (Yamaoka et al., 1981) was used to analyze the two curves, which were gotten with or without inhibitor in each reaction to calculate Vmax, $\mathrm{Km}$ and $\mathrm{Ki}$.

\section{Statistical analysis:}

Data of treated groups were compared with those of control group to determine the significancy of tebufenozide effects on liver CYPs. After oral administration of tebufenozide, one way ANOVA was used followed by Dunnett's multiple comparison test in case of equal variances, while Kruskal-Wallis test was applied in case of unequal variances. In case of in vitro study, Student's t-test was used. The statistical probability was considered significant at $\mathrm{P} \leq 0.05$.

\section{RESULTS}

\section{Effects of oral administration of tebufenozide on hepatic CYP activities:}

Figure (1) shows the effects of tebufenozide on the liver microsomal activities of EROD, TBH, BLH and MDZH after oral administration for 5 consecutive days, my results revealed no any significant alteration in the activities of the tested microsomal enzymes after tebufenozide treatment.

\section{Inhibition study:}

Figure 2 exhibits Michaelis-Menten kinetics of the EROD, TBH, BLH and MDZH with or without tebufenozide in the assay system. Table 1 demonstrates kinetic parameters concerning Vmax, Km and inhibition constant (Ki) for each reaction. In the all reactions tebufenozide showed a quite small inhibitory effects with high Ki values as indicated in Table 1. In case of CYP 2D the inhibition was significant only at the substrate concentrations of 4 and $17 \mu \mathrm{M}$ 
Fig. 1. Effects of tebufenozide on metabolic reactions catalyzed by CYP1A, 2C, 2D, and $3 \mathrm{~A}(1 \mathrm{OH}$ and $4 \mathrm{OH})$ after oral administration for 5 days in rats

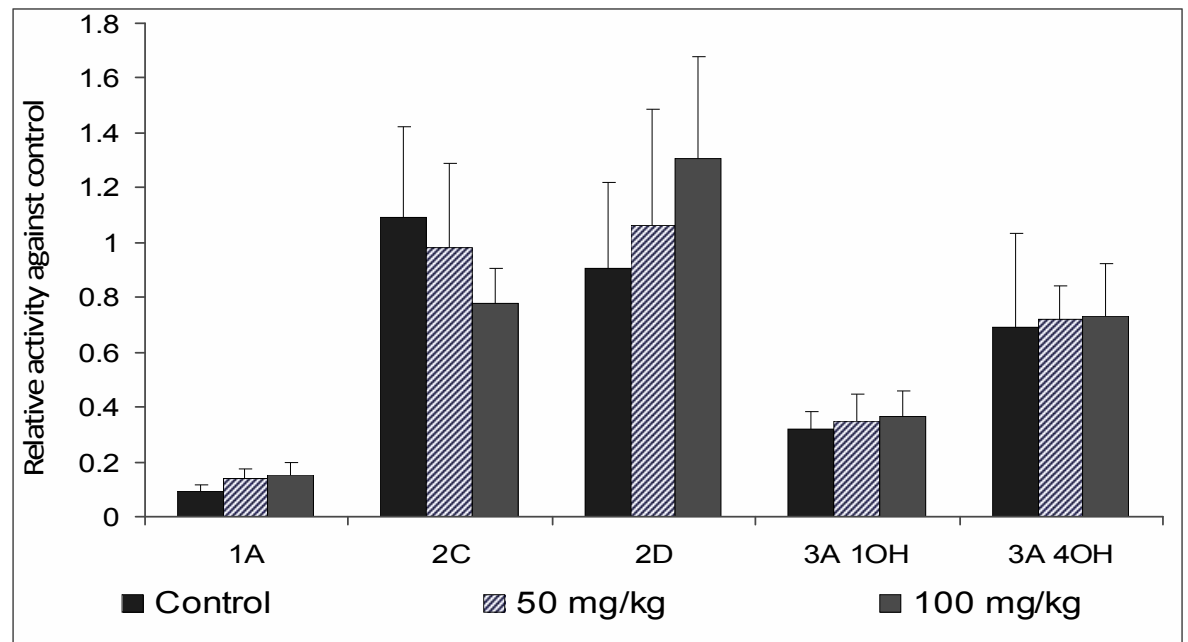

Bars represent relative reaction activities against control; error bars indicate $\mathrm{SD}$ of the mean $(\mathrm{n}=5)$

Fig. 2. Michaelis-Menten kinetics of EROD, TBH, BLH and MDZH in hepatic microsomes from rats. The solid curves represent the theoretical metabolic rates calculated using Vmax and Km values showed in Table 1.Closed and opened circles represent the observed metabolic rates (mean \pm $\mathrm{SD})$ in the presence or absence of tebufenozide, respectively.
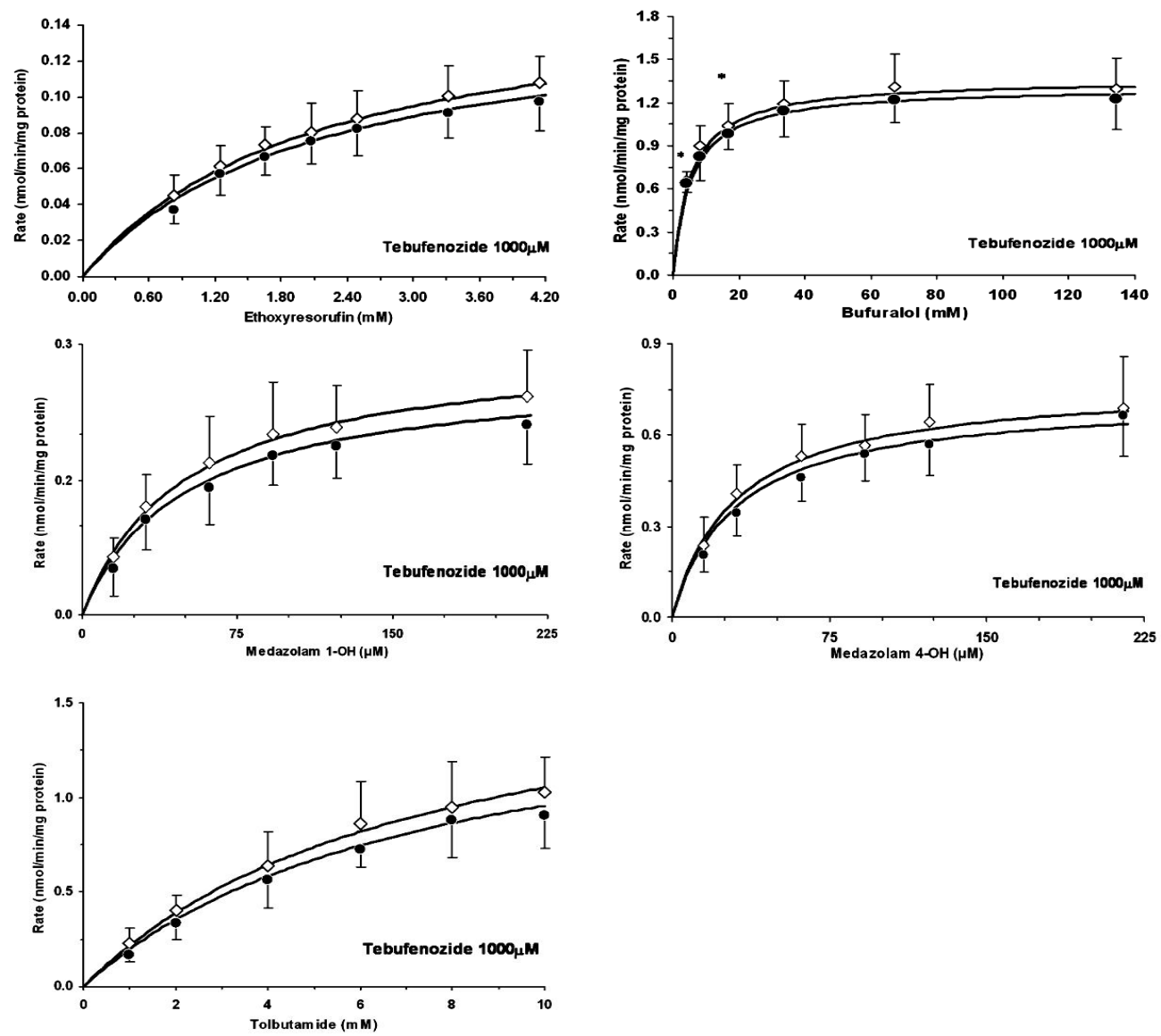
Table 1. Michaelis-Menten kinetic parameters for several metabolic reactions catalyzed by CYP subfamilies in the presence or absence of tebufenozide in liver microsomes of rats

\begin{tabular}{lccc}
\hline \multicolumn{1}{c}{$\begin{array}{c}\text { CYP metabolic } \\
\text { reactions }\end{array}$} & \multicolumn{3}{c}{ Kinetic parameters } \\
\cline { 2 - 4 } & $\boldsymbol{V}_{\boldsymbol{m a x}}$ & $\boldsymbol{K}_{\boldsymbol{m}}$ & $\boldsymbol{K}_{\boldsymbol{i}}$ \\
\hline EROD & $0.16 \pm 2.03$ & $2.06 \pm 0.20$ & $14574 \pm 4493$ \\
TBH & $1.63 \pm 0.40$ & $7.62 \pm 1.37$ & $9880 \pm 2406$ \\
BLH & $1.41 \pm 0.27$ & $5.16 \pm 1.41$ & $21480 \pm 4431$ \\
MDZH 1OH & $0.36 \pm 0.19$ & $48.4 \pm 6.82$ & $9131 \pm 3766$ \\
MDZH 4OH & $0.70 \pm 0.11$ & $29.7 \pm 7.80$ & $14734 \pm 3327$ \\
\hline
\end{tabular}

Each value represented by mean $\pm \mathrm{SD}(\mathrm{n}=5)$. Vmax (nmol/min/mg protein), Km $(\mu \mathrm{M})$, and Ki $(\mu \mathrm{M})$ were estimated using a nonlinear least square fitting program.

\section{DISCUSSION}

Cytochrome P450 enzymes are necessary for metabolism and detoxification of many xenobiotic; these enzymes can be inhibited or induced by chemicals. Induction of hepatic CYP enzymes may result in accumulation of the reactive metabolites of exposed xenobiotics leading to cancer ( $\mathrm{Ma}$ and $\mathrm{Lu}, 2007$ ), Also it may modify a patient's response to the drugs causing toxicities or medicinal failures. Moreover, enzyme inhibition is of major interests in toxicology, but available information about this issue is very limited (Abdou et al., 2010). Generally, the insect growth regulators are considerably safe for human and other environmental forms and of great selectivity of action and Many IGRs are labeled "reduced risk" by the Environmental Protection Agency (Mondal and Parween, 2000, Gilbert, 2009 and Pimentel 2010) but, further researches are required to ascertain its safety as its effects on the activities of liver microsomal enzymes, however, are not well known. It is well known that ecdysteroids control the different physiological and biochemical changes that are required for insect growth and moulting so that, chemicals interfering with this insect hormone have attracted the attention of many researchers since 1988. Tebufenozide (RH-5992) represent a new class of insect growth regulatory insecticides that induce a lethal moult in various insect larvae by stimulating the ecdysteroid receptors, it possesses a high selective toxicity and considered as non toxic depending on the normal toxicological protocols therefore, it used in the control of agricultural and fruit pests (Kreutzweiser and Thomas, 1995, Smagghe et al., 1997, Gilbert, 2009). As a part of research efforts to evaluate the hazards and environmental danger of tebufenozide we conducted this study to characterize its possible effects on the activities of hepatic CYP isoenzymes. 
6 - 9 September 2014

My data revealed that tebufenozide, as an example of IGRs, had no any considerable effects on the hepatic CYP reactions neither in case of in vitro nor in vivo studies. There was a significant inhibition on CYP 2D in some substrate concentrations; but the very high $\mathrm{Ki}$ value $(9880 \mu \mathrm{M})$ reflects no clinical inhibitory effect of tebufenozide on CYP2D. In a previous study we found that cyromazine (another member of IGRs) affected the liver CYPs only in a lesser extent, along with the present study, it can be expected that IGR group may be relatively safe in comparison with the other insecticide groups, but this proposition need to be approved by further researches on other members of the same group. If the further studies indicated that suggestion is right we would recommend the using of this group other than pyrethroid and organophosphorus. IGR can be a good alternate for strategic uses but doubtful in tactical uses as it does not affect the adult stages of the insects.

As a conclusion, we can assume that tebufenozide can be considered safer for the life forms than other commercial insecticides. 


\section{REFERENCES}

Abdou R, Sasaki K, Khalil W, Shah S, Murasawa Y, Shimoda M. (2010). Effects of several pyrethroids on hepatic cytochrome P450 activities in rats. J Vet Med Sci. 72:425-33.

Bibi Z. (2008). Role of cytochrome P450 in drug interactions. Nutrition \& Metabolism. 5:27.

Bradford, M. M. (1976). A rapid and sensitive method for the quantitation of microgram quantities of protein utilizing the principle of protein-dye binding. Anal. Biochem. 72: $248-254$.

Burke, M. D., Prough, R. A. and Mayer, R. T. (1977). Characteristics of microsomal cytochrome P-448-mediated reaction, ethoxyresorufi O-deethylation. Drug Metab. Dispos. 5: 1-8.

Carlson GR (2000). Tebufenozide: A novel caterpillar control agent with unusually high target selectivity. In "Green Chemical Syntheses and Processes" (ed.s: P. T. Anastas, L. G. Heine, T. C. Williamson). Am. Chem. Soc. 767: 8-17.

Chow, T., Imaoka, S., Hiroi, T. and Funae, Y. (1999). Developmental changes in the catalytic activity and expression of 2D isoforms in the rat liver. Drug Metab. Dispos. 27: 188-192.

Easterbrook, J., Fackett, D. and Li, A. P. (2001). A comparison of aroclor 1254-induced and uninduced rat liver microsomes to human liver microsomes in phenytoin Odeethylation, coumarin 7-hydroxylation, tolbutamide 4-hydroxylation, Smephenytoin 4'-hydroxylation, chloroxazone 6-hydroxylation and testosterone 6-hydroxylation. Chem. Biol. Interact. 134: 243-249.

FAO/WHO (1996). Pesticide Residues in Food - 1996: Report of the Joint Meeting of the FAO Panel of Experts on Pesticide Residues in Food and the Environment and the WHO Expert Group on Pesticide Residues, Rome, Italy.

Gilbert L I. (2009). Insect development: morphogenesis, molting and metamorphosis. Amsterdam, Elsevier/Academic Press. 1st ed. pp: 698.

Glue, P. and Clement, R. P. 1999. Cytochrome P450 enzymes and drug metabolism—basic concepts and methods of assessment. Cell. Mol. Neurobiol. 19: 309-323. 
6 - 9 September 2014

Guengerich FP. (2008). Cytochrome p450 and chemical toxicology. Chem Res Toxicol. 21:70-83.

Hamadah Kh.Sh., Ghoneim K.S. and Tanani M.A. (2012). Effect of certain insect growth regulators on the lipid content of some tissues of the desert locust Schistocerca gregaria. African Journal of Biochemistry Research. 6(9): 121-128.

Hami, M., Taibi, F., Smagghe, G. and Soltani-Mazouni, N. (2005). Comparative toxicity of three ecdysone agonist insecticides against the Mediterranean flour moth. Commun Agric. Appl. Biol. Sci. 70: 767-73.

Hanioka, N., Tatarazako, N., Jinno, H., Arizono, K. and Ando, M. 2000. Determination of cytochrome P450 1A activities in mammalian liver microsomes by high-liquid chromatography with fluorescence detection. J. Chromatogr. B Biomed. Sci. Appl. 744: 399-406.

Kotegawa, T., Laurijssens, B. E., Von Moltke, L. L., Cotreau, M. M., Perloff, M. D., Venkatakrishnan, K., Warrington, J. S., Granda, B. W., Harmatz, J. S. and Greenblatt, D. J. 2002. In vitro, pharmacokinetic, and pharmacodynamic interactions of ketoconazole and midazolam in the rat. J. Pharmacol. Exp. Ther. 302: $1228-1237$.

Kreutzweiser DP, Thomas DR. (1995). Effects of a new molt-inducing insecticide, tebufenozide, on zooplankton communities in lake enclosures. Ecotoxicology. 4:30728.

Kronbach, T., Mathys, D., Gut, J., Catin, T. and Meyer, U. A. 1987. High performance liquid chromatographic assay for bufuralol 1-hydroxylase, debrisoquine 4hydroxylase, and dextromethorphan O-deethylase in microsomes and purified cytochrome P-450 isozymes of human liver. Anal. Biochem. 162: 24-32.

Kuroha, M., Azumano, A., Kuze, Y., Shimoda, M. and Kokue, E. 2002. Effect of multiple dosing of ketoconazole on pharmacokinetics of midazolam, a cytochrome P-450 3A substrate in beagle dogs. Drug Metab. Dispos. 30: 63-68.

Lynch T and Price A. (2007). The Effect of Cytochrome P450 Metabolism on Drug Response, Interactions, and Adverse Effects. Am Fam Physician. 76:391-396. 
Ma, Q. and Lu, A. Y. 2007. CYP1A induction and human risk assessment: an evolving tale of in vitro and in vivo studies. Drug Metab. Dispos. 35: 1009-1016.

Merzendorfer H, Kim HS, Chaudhari SS, Kumari M, Specht CA, Butcher S, Brown SJ, Manak JR, Beeman RW, Kramer KJ,Muthukrishnan S. (2012). Genomic and proteomic studies on the effects of the insect growth regulator diflubenzuron in the model beetle species Tribolium castaneum. Insect Biochem Mol Biol. 42:264-76 .

Miners, J. O., Smith, K. J., Robson, R. A., McManus, M. E., Veronese, M. E. and Birkett, D. J. 1988. Tolbutamide hydroxylation by human liver microsomes; kinetic characterization and relationship to other cytochrome P-450 dependent xenobiotics oxidations. Biochem. Pharmacol. 37: 1137-1144.

Mondal K. and Parween S (2000). Insect Growth Regulators and their Potential in theManagement of Stored-product Insect Pests. Integrated Pest Management Reviews. 5: 255-295.

Pimentel D. (2010). Encyclopedia of Pest Management. New York, Marcel Dekker Inc, CRC Press. pp: 400.

Retnakaran A, Gelbic I, Sundaram M, Tomkins W, Ladd T, Primavera M, Feng Q, Arif B, Palli R, Krell P (2001). Mode of action of the ecdysone agonist tebufenozide (RH-5992), and an exclusion mechanism to explain resistance to it. Pest Manag. Sci., 57:951-7.

Sadanandane C, Boopathi Doss PS, Jambulingam P. (2012). Efficacy of three formulations of diflubenzuron, an insect growth regulator, against Culex quinquefasciatus Say, the vector of Bancroftian filariasis in India. Indian J Med Res. $136: 783-91$.

Schneider E, Clark DS. (2013). Cytochrome P450 (CYP) enzymes and the development of CYP biosensors. Biosens Bioelectron. 39:1-13.

Smagghe G., Viñuela E., Budia F. and Degheele1 D. (1997). Effects of the non-steroidal ecdysteroid mimic tebufenozide on the tomato looper Chrysodeixis chalcites Lepidoptera Noctuidae an ultrastructural analysis. Archives of Insect Biochemistry and and Physiology. 35: 179-190. 
Staal, G.B. (1975). Insect Growth Regulators with Juvenile Hormone Activity. Ann. Rev. of Entomol. 20: 417-460.

Suman, D. S., C. W. Brey, Y. Wang, M. Sanad, M. S. M. Shamseldean, and R. Gaugler. (2013). "effects of insect growth regulators on the mosquito - parasitic nematode Romanomermis iyengari". Parasitology Research. 112: 817-824.

Tasei, J.N. (2001). Effects of insect growth regulators on honey bees and non-Apis bees. Apidologie. 32: 527-545.

Tunaz H. and Uygun, N. (2004). Insect Growth Regulators for Insect Pest Control. Turk J Agric For. 28: 377-387.

Van der Hoeven, T. A. and Coon, M. J. 1974. Preparation and properties of partially purified cytochrome P-450 and reduced nicotinamide adenine dinucleotide phosphate-cytochrome P- 450 reductase from rabbit liver microsomes. J. Biol. Chem. 249: 6302-6310.

Yamaoka K., Tanigawara Y., Nakagawa T., and Uno T. (1981). A pharmacokinetic analysis program (MULTI) for microcomputer. J. Pharmacobiodyn. 4: 879-885. 


\section{الالغص العتبري \\ تأثيرات همفز هرهون الإكديسون الغير أستيرويدي - تيبـوفينهزايد علي الإيكروزوهات الكبدية}

$$
\text { رانيا حلمي بلدوي }
$$

مدرس الطب الشرعي والسموم ـ كلية الطب البيطري - جامعة قناة السويس

في هذه الدراستّ تم اعطاء مضاد هرمون الإكديسون غير الستيرويدي تيبوفينوزايد بالفم للفئران لمدة ه أيام

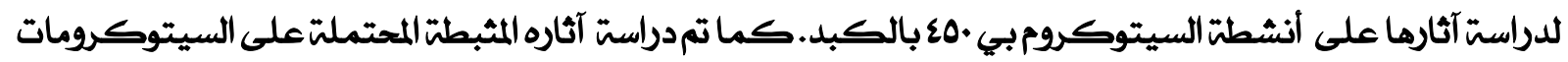
الكبديت من خلال قياس التفاعلات الأيضيت التي يحفزها السيتوكروم بي .0ء. وشملت هذه التفاعلات ايزوكسي

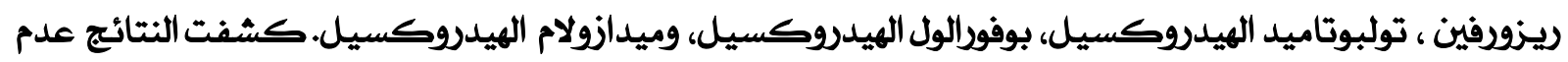

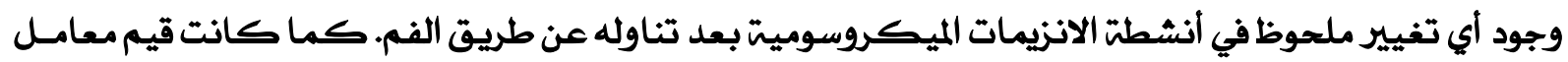

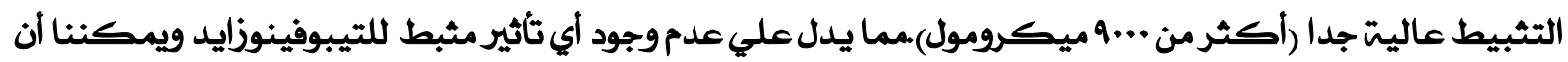
نعتبره آمن ويمكن أن يكون بديل جيد جيد للمبيدات الحشريت التقليديت. 